\title{
THE BIOCHEMICAL COMPOSITION OF PLANT RAW MATERIAL OF PANICUM VIRGATUM L. VARIETIES
}

\section{Vergun Olena*, Rakhmetov Djamal, Fishchenko Valentyna, Rakhmetova Svitlana, Shymanska Oksana, Bondarchuk Oleksandr}

M.M. Gryshko National Botanical Garden of Ukraine of National Academy of Sciences, Kyiv, Ukraine

Received 25. 6. 2017

Revised 29. 6. 2017

Published 30.11. 2017

In article represented the results of a biochemical study of nine varieties and one cultivar of Panicum virgatum $L$. The investigations were carried out in the stage of seed ripening that is the most productive phase for these plants. Plant raw material collected and analyzed in the department of the Cultural flora of M.M. Gryshko National Botanical Garden of NAS of Ukraine. The determination of dry matter was conducted by drying to constant mass; total content of saccharides and monosaccharides - by Bertrand method in water extracts; ascorbic acid - by 2.6-dichlorophenol-indophenol titration of acid extracts; carotene - by spectrophotometric method in petrol extracts; ash - by combustion at $300-800^{\circ} \mathrm{C}$; calcium and phosphorus - by titrimetric method in acid solutions. It's found that level of dry matter was in a range from $41.96 \%$ (Panicum virgatum f. SL-1) to $65.28 \%$ (Panicum virgatum $\mathrm{f}$. RB), total content of saccharides from $3.11 \%$ (Panicum virgatum f. RB) to $8.69 \%$ (Panicum virgatum cv. Zoriane), monosaccharides - from $1.50 \%$ (Panicum virgatum $\mathrm{f}$. RR) to $6.94 \%$ (Panicum virgatum f. DB), content of ash - from $3.04 \%$ (Panicum virgatum f. RR) to $5.27 \%$ (Panicum virgatum $\mathrm{f}$. SL-1), calcium - from $0.353 \%$ (Panicum virgatum f. SL-2) to $0.987 \%$ (Panicum virgatum f. PP), phosphorus - from $0.065 \%$ (Panicum virgatum f. RB) to $0.110 \%$ (Panicum virgatum f. VP), ascorbic acid - from $11.80 \mathrm{mg} \%$ (Panicum virgatum f. RB) to $61.94 \mathrm{mg} \%$ (Panicum virgatum cv. Zoriane), carotene - from $0.05 \mathrm{mg} \%$ (Panicum virgatum f. RB) to $1.06 \mathrm{mg} \%$ (Panicum virgatum f. DB). Energetic value of plant raw material was in a range from 4,102.00 Kcal/ kg (Panicum virgatum $\mathrm{f}$. DB) to $4,325.41 \mathrm{Kcal} / \mathrm{kg}$ (Panicum virgatum f. RB).

Keywords: Panicum virgatum L.; varieties; plant raw material; biochemical properties; energetic value

\section{Introduction}

Panicum virgatum L. (switchgrass) is a perennial grass native to the USA and Canada with an array of ploidy levels and ecotypes. It is used as a pasture and range grass for forage production (Huang et al., 2003). Last time these plants have characterized by using in a branch of biofuel production (Tigunova et al., 2016). Switchgrass doesn't require annual establishment, requires fewer chemical inputs (pesticide and fertilizer) than traditional row crops, produces large quantities of biomass and provides important ecosystem service. Some research has included work on breeding and genetics, ethanol potential, establishment, field-scale production economics, weed control, harvest and fertility management, documentation of the value of ecosystem services, energy balance, and entomology. The research to date fully supports that switchgrass for bioenergy is productive, protective of the environment and profitable for the farmer (Mitchell et al., 2012). Panicum virgatum is a C4 species

*Corresponding author: Olena Vergun, M.M. Gryshko National Botanical Garden of Ukraine of National Academy of Sciences, Kyiv, Ukraine, $₫$ en_vergun@ukr.net 
using the photosynthetic pathways that have higher photosynthetic, water, and nitrogen use efficiencies and greater tolerance to heat, nitrogen, and water stresses. These physiological attributes lead to high biomass productivity in switchgrass, especially under water- and nutrient-limited conditions (Parrish and Fike, 2005; Woli et al., 2012; Zegada-Lizarazu et al., 2012).

According to Kulyk (2015) and Kulyk (2016) the yield of a crude biomass of these plants was up to $24 \mathrm{~T} / \mathrm{ga}$ and dried biomass - up to $20 \mathrm{~T} / \mathrm{ga}$ depends on the group of ripeness. The main components of the switchgrass biomass are cellulose (35\%), hemicellulose (29\%), and lignin (26\%) (Jefferson and McCaughey, 2012; Tigunova and Shulga, 2015). The maximal chlorophyll values were observed during anthesis (Liatukas, 2015).

\section{Materials and methodology}

Plant raw material collected from the experimental collections of Cultural Flora department of M.M. Gryshko National Botanical Garden of the NAS of Ukraine. All biochemical analyses were conducted using the above-ground part of plants of Panicum virgatum varieties. The determination of absolutely dry matter conducted with drying to constant weight at $100-105^{\circ} \mathrm{C}$ according to Yermakov (1972). The total content of saccharides and monosaccharides were investigated by Bertrand method in water extracts. The concentration of ascorbic acid (AA) of the acid extracts determined by a 2.6-dichlorophenol-indophenol method that based on the reduction properties of AA. Both analyses carried out according to V.P. Krishchenko (1983). The concentration of total carotene determined according to Pleshkov (1985). The procedure carried out in petrol extracts by spectrophotometric method using 2800 UV/VIS Spectrophotometer, Unico. Mixtures were left in a shaker for 2 hours and their absorbance was measured at the wavelength of $440 \mathrm{~nm}$ (Плешков, 1985). The level of total ash was determined using the method of combustion in muffle-oven (SNOL 7.2-1100, Termolab) at $300-800^{\circ} \mathrm{C}$ until the samples turned into white ash to constant weight according to Z.M. Hrycajenko et al. (2003). The concentration of calcium was determined by titration method of acid extracts with Trilon B. Phosphorus content in plants was identified in acid extracts using molybdenum solution. Calcium and phosphorus determination carried out according to H.N. Pochinok (1976). To measure of the caloric value of seeds was equipped with a calorimeter IKA C-200 (Germany). Dry plant raw material in a range from 0.1 to $0.2 \mathrm{~g}$ was put in the decomposition vessel (IKA C 5010/5012) that fills with medical oxygen. Experimental data were evaluated by using Excel 2010. Mean values of three replicates and standard deviations are given in Table 1, 2 and Figure 1.

\section{Results and discussion}

In the M.M. Gryshko National Botanical Garden have been investigated varieties and cultivars of Panicum virgatum (Рахметов та ін., 2015; Щербакова і Рахметов, 2017). Biochemical investigation of the plant has very important for evaluation raw material of a cultivated grasses. Maximizing dry matter yield is the primary objective when harvesting switchgrass for bioenergy (Mitchell et al., 2012). We identified among ten investigated samples that content of dry mass was in a range from 41.46 to $65.28 \%$.

Because of high productivity and quality of plant raw material, the leading position among energetic plants have a sugar-containing plants that is value source for biofuel production (Рахметов та ін., 2014). The total content of saccharides was from 3.11 to $8.69 \%$ and monosaccharides - from 1.50 to $6.94 \%$ depending on varieties. 
Table 1 The content of dry matter, total content of saccharides and monosaccharides in plant raw material of Panicum virgatum L. varieties in seed ripening phase, $\%$

\begin{tabular}{|l|c|c|c|}
\hline Sample & Dry matter & Total content of saccharides & Monosaccharides \\
\hline P. virgatum f. DB & $42.10 \pm 0.21$ & $7.91 \pm 0.48$ & $6.94 \pm 0.23$ \\
\hline P. virgatum f. DN & $43.86 \pm 0.26$ & $7.78 \pm 0.13$ & $3.76 \pm 0.27$ \\
\hline P. virgatum f. RB & $65.28 \pm 0.35$ & $3.11 \pm 0.37$ & $2.05 \pm 0.16$ \\
\hline P. virgatum f. PL & $43.42 \pm 0.19$ & $4.35 \pm 0.02$ & $3.75 \pm 0.30$ \\
\hline P. virgatum f. PP & $46.82 \pm 0.22$ & $8.23 \pm 0.15$ & $4.72 \pm 0.32$ \\
\hline P. virgatum f. RR & $58.34 \pm 0.04$ & $4.59 \pm 0.15$ & $1.50 \pm 0.11$ \\
\hline P. virgatum f. SL-1 & $41.96 \pm 0.88$ & $6.04 \pm 0.13$ & $4.44 \pm 0.03$ \\
\hline P. virgatum f. SL-2 & $44.31 \pm 0.30$ & $4.65 \pm 0.24$ & $3.08 \pm 0.18$ \\
\hline P. virgatum f. VP & $51.33 \pm 0.45$ & $6.19 \pm 0.10$ & $2.38 \pm 0.13$ \\
\hline P. virgatum cv. Zoriane & $50.45 \pm 0.36$ & $8.69 \pm 0.27$ & $5.95 \pm 0.12$ \\
\hline
\end{tabular}

In Table 2 represented the content of ash, calcium, and phosphorus in above-ground part of different varieties of Panicum virgatum L. in the period of seed ripening. Investigated plants characterised by the content of ash in a range from 3.19 to $5.27 \%$. In our previous data, we analysed four varieties and one cultivar: Panicum virgatum f. VP, Panicum virgatum f. RB, Panicum virgatum f. VP and Panicum virgatum cv. Zoriane. According to obtained results, the content of dry matter was 40.70, 42.52, 36.06 and $37.14 \%$ respectively. Above-ground part of these plants accumulated $4.36 \%$ (Panicum virgatum f. VP), $4.70 \%$ (Panicum virgatum f. RB), 6.90\% (Panicum virgatum f. VP) and $7.32 \%$ (Panicum virgatum cv. Zoriane) of the total content of saccharides (Рахметов та ін., 2014). As shown in Table 1 the content of monosaccharides was from $1.50 \%$ (Panicum virgatum $\mathrm{f}$. RR) to $6.94 \%$ (Panicum virgatum $\mathrm{f}$. DB).

Table 2 The content of ash in plant raw material of Panicum virgatum L. varieties in seed ripening phase, \%

\begin{tabular}{|l|c|c|c|}
\hline Sample & Ash & Calcium & Phosphorus \\
\hline P. virgatum f. DB & $3.47 \pm 0.16$ & $0.360 \pm 0.060$ & $0.074 \pm 0.001$ \\
\hline P. virgatum f. DN & $4.70 \pm 0.13$ & $0.610 \pm 0.010$ & $0.088 \pm 0.002$ \\
\hline P. virgatum f. RB & $4.02 \pm 0.16$ & $0.823 \pm 0.095$ & $0.065 \pm 0.000$ \\
\hline P. virgatum f. PL & $4.33 \pm 0.18$ & $0.427 \pm 0.055$ & $0.097 \pm 0.004$ \\
\hline P. virgatum f. PP & $4.83 \pm 0.52$ & $0.987 \pm 0.015$ & $0.085 \pm 0.001$ \\
\hline P. virgatum f. RR & $3.04 \pm 0.48$ & $0.397 \pm 0.045$ & $0.074 \pm 0.000$ \\
\hline P. virgatum f. SL-1 & $5.27 \pm 0.09$ & $0.443 \pm 0.025$ & $0.066 \pm 0.000$ \\
\hline P. virgatum f. SL-2 & $3.97 \pm 0.08$ & $0.353 \pm 0.075$ & $0.082 \pm 0.004$ \\
\hline P. virgatum f. VP & $3.19 \pm 0.19$ & $0.597 \pm 0.055$ & $0.110 \pm 0.005$ \\
\hline P. virgatum cv. Zoriane & $3.50 \pm 0.03$ & $0.983 \pm 0.015$ & $0.076 \pm 0.005$ \\
\hline
\end{tabular}




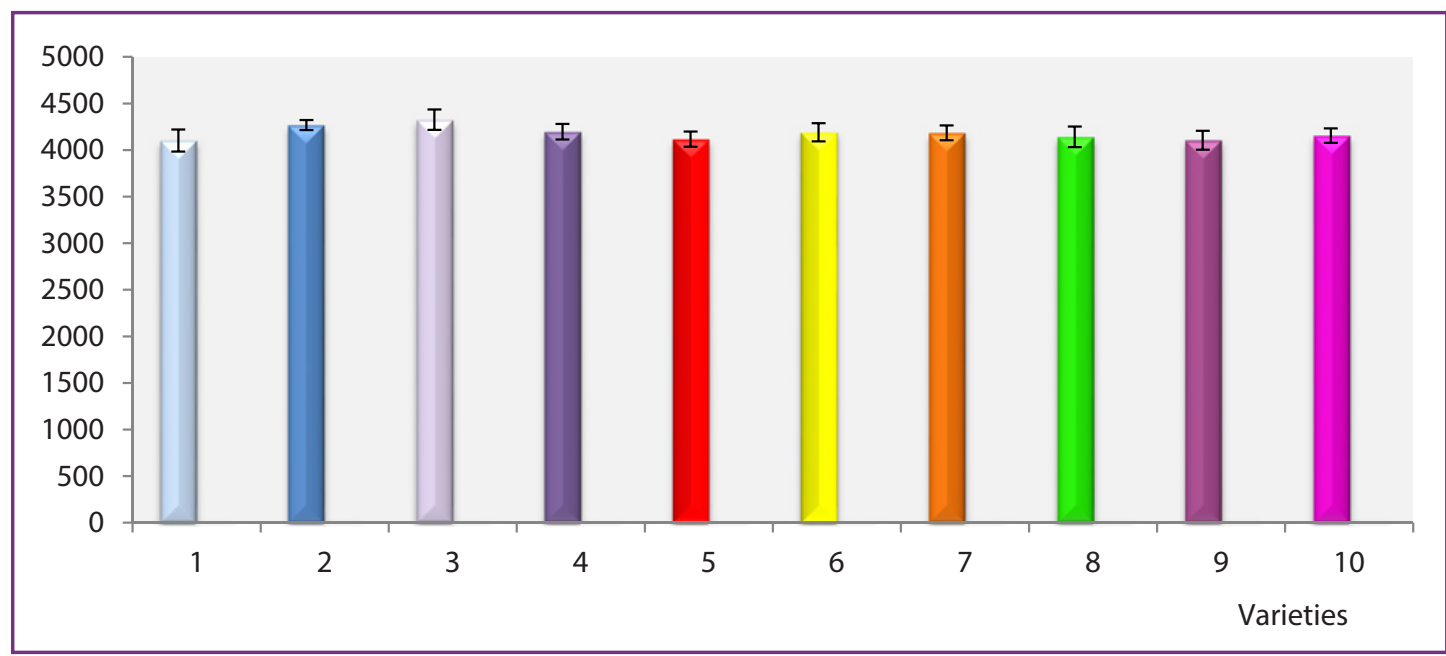

Figure 1 The energetic value of the plant raw material of Panicum virgatum $\mathrm{L}$. varieties in a seed ripening phase, $\mathrm{Kcal} / \mathrm{kg}$

1- Panicum virgatum f. DB, 2 - Panicum virgatum f. DN, 3 - Panicum virgatum f. RB, 4 - Panicum virgatum f. PL, 5 - Panicum virgatum f. PP, 6 - Panicum virgatum $\mathrm{f}$. RR, 7 - Panicum virgatum f. SL-1, 8 - Panicum virgatum f. SL-2, 9 - Panicum virgatum f. VP, 10 - Panicum virgatum cv. Zoriane

Biomass properties such as ash composition can affect energy conversion processes such as direct combustion (Zhuo et al., 2015). Investigations of ash content showed that this sign was in a range from 3.04\% (Panicum virgatum f. RR) to 5.27 (Panicum virgatum f. SL-1) \%. As reported Hu et al. (2010), the ash content of Panicum virgatum L. was from 0.4 to $4.6 \%$ depends on switchgrass population.

We identified that maximal content of calcium in ash was $0.987 \%$ (Panicum virgatum f. PP) and minimal $-0.353 \%$ (Panicum virgatum $\mathrm{f}$. SL-2). The concentration of phosphorus was in a range from 0.065\% (Panicum virgatum f. RB) to 0.110 (Panicum virgatum f. VP).

We investigated the accumulation of ascorbic acid in phase ripening phase. The content of ascorbic acid wasn't significant for all investigated plants. Panicum virgatum f. DB accumulates $19.27 \mathrm{mg} \%$, Panicum virgatum f. DN - 30.09 mg\%, Panicum virgatum f. RB - 11.80, Panicum virgatum f. PL - $13.94 \mathrm{mg} \%$, Panicum virgatum f. PP - 28.20 mg\%, Panicum virgatum f. RR - 13.44 mg\%, Panicum virgatum f. SL-1 13.70 mg\%, Panicum virgatum f. SL-2 - 18.62 mg\%, Panicum virgatum f. VP - 27.86 mg\%, Panicum virgatum cv. Zoriane - $61.94 \mathrm{mg} \%$. According to Rakhmetov et al. (2014) the accumulation of ascorbic acid in above-ground part was $59.84 \mathrm{mg} \%$ (Panicum virgatum f. VP), $42.07 \mathrm{mg} \%$ (Panicum virgatum cv. Zoriane), and $23.28 \mathrm{mg} \%$ (Panicum virgatum $\mathrm{f} . \mathrm{RB}$ ).

It was investigated the content of carotene in above-ground part of plants of Panicum virgatum. Research showed that Panicum virgatum f. DB in the seed ripening period accumulates $1.06 \mathrm{mg} \%$, Panicum virgatum f. DN - 0.16 mg\%, Panicum virgatum f. RB - $0.05 \mathrm{mg} \%$, Panicum virgatum f. PL $0.62 \mathrm{mg} \%$, Panicum virgatum f. PP - $0.71 \mathrm{mg} \%$, Panicum virgatum f. RR - $0.61 \mathrm{mg} \%$, Panicum virgatum f. SL-1 - 0.32 mg\%, Panicum virgatum f. SL-2 - 0.74 mg\%, Panicum virgatum f. VP - $0.55 \mathrm{mg} \%$, Panicum virgatum cv. Zoriane $-0.81 \mathrm{mg} \%$. As identified Rakhmetov et al. (2014) the content of carotene was $0.21 \mathrm{mg} \%$ (Panicum virgatum f. VP), $0.42 \mathrm{mg} \%$ (Panicum virgatum cv. Zoriane), and $0.43 \mathrm{mg} \%$ (Panicum virgatum f. RB). 
It's should be noted that among investigated plants ws in a range from 4,102.00 Kcal/kg (Panicum virgatum f. DB) to 4,325.41 (Panicum virgatum f. RB). As showed previous data, obtained by Rakhmetov et al. (2014) the energetic value of plant arwmaterial was from 4,011.67 to $4,349.67 \mathrm{Kcal} / \mathrm{kg}$.

\section{Conclusions}

Results showed that in conditions of M.M. Gryshko National Botanical Garden among the investigated plants the leader of accumulation of dry matter and calories was Panicum virgatum f. RB. Maximal sign of total content of saccharides and concentration of ascorbic acid was characterized for Panicum virgatum cv. Zoriane. The most content of monosaccharides and carotene found in plant raw material of Panicum virgatum $\mathrm{f}$. DB. The higher level of ash observed in sample Panicum virgatum f. SL-1, calcium - in Panicum virgatum f. PP and phosphorus - in Panicum virgatum f. VP. To conclude, investigated plants of Panicum virgatum L. can be used not only as energetic plants but as fodder crops.

\section{References}

Hu, Z., Sykes, R., Davis, M.F., Brummer, E.C., Ragauskas, A.J. 2010. Chemical profiles of switchgrass. Bioresource Technology, vol. 101, p. 3253-3257.

Huang, S., Su, X., Haselkorn, R., Gornicki, P. 2003. Evolution of switchgrass (Panicum virgatum L.) based on sequences of the nuclear gene encoding plastid acetyl-CoA carboxylase. Plant Science, vol. 164, p. 43-49.

Jefferson, P.G., McCaughey, M.P. 2012. Switchgrass (Panicum virgatum L.) cultivar adaptation, biomass production, and cellulose concentration as affected by latitude of origin. ISRN Agronomy, vol. 2012, Article ID 763046. doi:10.5402/2012/763046

Liatukas, Z., Lemeziene, N., Butkute, B., Ceseviciene, J., Dabkeviciene, C. 2015. Chlorophyll values as a measure of genetic variation of switchgrass (Panicum virgatum $L$.) populations under cool temperate climate conditions. Zemdirbyste-Agriculture, vol. 102, no. 2, p. 159-166. DOI 10.13080/z-a.2015.102.021

Mitchell, R., Vogel, K.P., Uden, D.R. 2012. The feasibility of switchgrass for biofuel production. Biofuels, vol. 3, no. 1, p. 47-59.

Parrish, D.J, Fike, J.H. 2005. The biology and agronomy of Switchgrass for Biofuels. Critical Reviews in Plant Sciences, vol. 24, no. 5-6, p. 423-459.

Tigunova, O.O., Shulga, S.M. 2015. New strain-producers of biobutanol. III. Methods of increased butanol accumulation from biomass of switchgrass Panicum virgatum L. Biotechnologia Acta, vol. 8, no. 4, p. 92-97. DOI:10.15407/biotech8.04.092

Tigunova, O.O., Beiko, N.E., Andriiash, A.S., Priymov, S.G., Shulga, S.M. 2016. Liophilization effect on productivity of butanol-producting strains. Biotechnologia Acta, vol. 9, no. 5, p. 24-29. https://doi.org/ 10.15407/biotech9.05.024

Woli, P., Paz, J.O., Lang, D.J., Baldwin, B.S., Kiniry, J.R. 2012. Soil and variety effect on the energy and carbon balances of switchgrass-derived ethanol. Journal of Sustainable Bioenergy Systems, vol. 2, p. 65-74. http://dx.doi.org/10.4236/jsbs.2012.24010

Zegada-Lizarazu, W., Wullschleger, S.D., Nair, S.S., Monti, A. 2012. Crop Physiology In Monti, A. Switchgrass: A valuable Biomass Crop for Energy. London: Springer-Verlag, p. 55-86.

Zhuo, Y., Zhang, Y., Xie, G., Xiong, S. 2015. Effects of salt stress on biomass and ash composition of switchgrass (Panicum virgatum). Acta Agriculturae Scandinavica, Section B-Soil and Plant Science, vol. 65, no. 4, p. 300-309. http://dx.doi.org/10.1080/09064710.2015.1006670

Грицаєнко, 3.М., Грицаєнко, А.О., Карпенко, В.П. 2003. Методи біологічних та агрохімічних досліджень рослин і грунтів. Київ: НІЧЛАВА. 320 с. ISBN 966-7317-84-6. 
Ермаков, А.И., Арасимович, В.В., Смирнова-Иконникова, М.И. 1972. Методы биохимического исследования растений. Ленинград: Колос. 456 с.

Крищенко, В.П. 1983. Методы оценки качества растительной продукции. Москва: Колос, 192 с.

Кулик, М.И. 2015. Адаптивный потенциал проса прутьевидного в условиях Украины. Вестник Курганской ГСХА, № 1, с. 28-30.

Кулик, М.И. 2016. Урожайність сортів проса прутоподібного п'ятого року вегетації залежно від біометричних показників рослин. Вісник Полтавської державної аграрної академії, №1-2, c. 30-35.

Плешков, Б.П. 1985. Практикум по биохимии растений. Москва: Колос. 256 с.

Починок, Х.Н. 1976. Методы биохимического анализа растений. Київ, Наук. Думка. 336 с.

Рахметов, Д.Б., Корабльова, О.А., Стаднічук, Н.А., Андрущенко О.Л., Ковтун-Водяницька С.М. 2015. Каталог рослин відділу нових культур. Київ: Фітосоціоцентр. 112 с.

Щербакова, Т., Рахметов, Д. 2017. Особливості будови пагонів проса прутоподібного (Panicum virgatum L.) в умовах інтродукції в Правобережному Лісостепу та Поліссі України. Сортовивчення та охорона прав на сорти рослин, №1, с. 85-88. http://dx.doi.org/10.21498/2518-1017.13.1.2017.97334 